\title{
KONSTYTUCYJNE PUBLICZNE PRAWO GOSPODARCZE
}

W normatywnym oznaczeniu tożsamości gospodarki rynkowej podstawowe miejsce zajmuje wolność działalności gospodarczej przedsiębiorcy. Wolność gospodarcza stanowi przedmiot ujęcia normatywnego przede wszystkim w rozwiązaniach konstytucyjnych. Brak zainteresowania ustrojodawcy co do wyróżnienia wolności gospodarczej czy ujęcia jej cech znamiennych, wyrażony przez odesłanie do ustawodawstwa zwykłego jako właściwego do nadawania wolności określonych treści, oznaczałby w istocie uznanie jej za wartość, której miejsce i znaczenie w katalogu instytucji prawnych gospodarki rynkowej wyznaczają koniunkturalnie przyjmowane poglądy i stanowiska oraz leżące u ich podstaw oceny, formułowane w wyniku sporów o wartości polityczne.

Publiczne prawo gospodarcze jest dziedzina polskiego systemu prawa, która przejmuje w regulacjach prawnych stanowisko polskiego ustrojodawcy w sprawach działalności gospodarczej i sytuacji jej podmiotów. Niewątpliwie taką instytucją polskiego prawa konstytucyjnego, implementowana przez publiczne prawo gospodarcze jest wolność działalności gospodarczej. Pogląd ten nie jest oryginalny, każda co do zasady regulacja jest bowiem zakorzeniona $\mathrm{w}$ instytucjach i wartościach konstytucyjnych. Konstytucyjnie zaakceptowana i ujęta wolność gospodarcza wyznacza tym samym kierunki regulacji publicznego prawa gospodarczego. Ustalone w jej treści wartości w istocie przesądzają o ustroju organizacyjno-prawnym systemu gospodarczego, w którym pozycję podmiotów działalności gospodarczej określają regulacje determinowane przez konstytucyjny wyraz wolności przedsiębiorczości. Regulacje szczegółowe publicznego prawa gospodarczego nie sa więc przyjmowane w swego rodzaju normatywnej próżni aksjologicznej; to właśnie konstytucyjnie ujęta wolność gospodarcza jest odniesieniem do stanowiska ustawodawcy w kształtowaniu treści regulacji szczegółowych o przedsiębiorczości i jej podmiotach - tak w stosunkach wzajemnych między przedsiębiorcami, jak też co do ich sytuacji prawnej wobec władz publicznych w stosunkach wertykalnych. Uprawnione jest przekonanie, że system gospodarczy bez konstytucyjnie ujętej afirmacji wolności gospodarczej oraz gwarancji jej urzeczywistniania pozostałby tylko pewną iluzją rynku - bez właściwych dla niego mechanizmów i instytucji prawnych. Pośród nich najistotniejsze znaczenie ma wolność podmiotów do 
przedsiębiorczości oraz prawa szczegółowe, które wyznaczają i kształtują swobody przedsiębiorców do organizowania sposobu jej wykonywania.

Wolność gospodarcza jako wartość szczególna, determinująca istotę ustroju polskiego systemu gospodarczego jest obecna od przywrócenia do porządku rozwiązań konstytucyjnych podstawowych instytucji i mechanizmów właściwych demokratycznemu państwu prawnemu. Szczególne znaczenie w ustalaniu konsekwencji tej konstytucyjnej obecności wolności gospodarczej przyznano Trybunałowi Konstytucyjnemu. Sądzę, że uwzględnienie dorobku orzeczniczego polskiego sądu konstytucyjnego pozwala nie tylko na właściwe ustalenie miejsca i znaczenia wolności gospodarczej w systematyce wartości ujętych w Konstytucji. Trybunał wskazał także na zasady i przesłanki, które rządzą interpretacjami jej ujęcia konstytucyjnego, jak też przy aplikacji wyników takich interpretacji w procesach stanowienia prawa szczegółowego dla publicznoprawnych i prywatnoprawnych stosunków w gospodarce.

Stanowisko trybunalskie pełni szczególną rolę zwłaszcza w analizach zasadności podejmowania przez ustawodawcę inicjatyw ograniczania wolności gospodarczej czy weryfikacji przyjętych aktów normatywnych, kiedy podstawowym kryterium oceny jest ich zgodność z konstytucyjnie wyznaczona wolnością gospodarczą. W dalszych rozważaniach podjęta zostanie próba ustalenia, czy i w jakim stopniu regulacje konstytucyjne oraz ich trybunalska wykładnia pozostają w istotowych relacjach z rozwiązaniami publicznego prawa gospodarczego. Szczególnym bowiem dzisiaj wyzwaniem dla nauki publicznego prawa gospodarczego jest nie tylko przywoływanie i charakteryzowanie tych wartości konstytucyjnych, które przesądzają o przedmiocie regulacji i zasadach ujmowania normatywnego przedsiębiorczości. Pośród tych wartości podstawowe znaczenie ustrojodawca odnosi do wolności gospodarczej. Celowe wydaje się wyznaczanie także nowych perspektyw badawczych przez charakteryzowanie obecności w regulacjach publicznego prawa gospodarczego (kierunki regulacji) ujęć konstytucyjnych oraz nadawanej im przez Trybunał Konstytucyjny interpretacji znaczeniowej.

Wolność przedsiębiorczości jest przypisana do konkretnych podmiotów, które uznajemy przez to za podmioty wolności gospodarczej. Tym samym w zainteresowaniach badawczych nad wolnością przedsiębiorczości zwracamy uwage na katalog (krag) podmiotów, które są uprawnione do wolności przedsiębiorczości w ujęciu konstytucyjnym. Podmiotami tymi sa przede wszystkim osoby fizyczne oraz inne podmioty prawa (jednostki organizacyjne), które czerpią swoje prawo do przedsiębiorczości i przywiązane do niej prawo do wolności gospodarczej z treści właściwych regulacji prawnych.

Wolność gospodarcza (działalności gospodarczej) wyznacza sytuację jednostki (osoby fizycznej, jednostki organizacyjnej - podmiotów prawa) w związku z podejmowaniem lub wykonywaniem przedsiębiorczości. Wolność tę wywodzimy z godności osoby fizycznej (art. 30 Konstytucji). Uznanie godności 
przez jej uwzględnienie w kategoriach i ujęciach prawnych oznacza zarazem poszanowanie zakotwiczonej w jej treści wolności gospodarczej. Podobnej weryfikacji podlega sytuacja jednostek organizacyjnych, które są uprawnione (zobowiązane) do podejmowania i wykonywania działalności gospodarczej (przedsiębiorczości). Źródłem ich wolności gospodarczej jest bowiem wolność osoby ludzkiej, jeżeli za sytuacją jednostek organizacyjnych kryją się wartości, które wiążemy z jednostkami (osobami fizycznymi) ${ }^{1}$. Stan taki powstawać może zwłaszcza wówczas, kiedy osoby fizyczne tworzą (zakładaja, powołuja) podmioty przedsiębiorczości lub też uczestniczą w takich przedsięwzięciach za pośrednictwem innych jednostek organizacyjnych, w których partycypuja na zasadach prawnie określonych. Wolność gospodarcza jednostek organizacyjnych nie jest jednak stanem naturalnym w znaczeniu przypisywanym wolności osoby ludzkiej. Ustawodawca może bowiem ją potwierdzać lub modyfikować jej cechy znamienne w sytuacji tych jednostek organizacyjnych, które spełniają wymagania wykonywania działalności gospodarczej.

Pogląd o związaniu sytuacji prawnej „zorganizowanych” podmiotów prawa ze statusem osób fizycznych ogarnia również - ale tylko co do zasady, która poddawana jest modyfikacjom w regulacjach prawnych - sytuację (zadania i kompetencje) państwa czy podmiotów publicznych (jednostek samorządu terytorialnego). Pogląd ten aktualizuje zarazem sytuację utworzonych przez państwo lub samorząd terytorialny jednostek organizacyjnych, które wykonują działalność gospodarczą i uczestniczą w przedsiębiorczości, jako odrębne podmioty przedsiębiorczości. Obecność państwa lub jednostek samorządu terytorialnego $\mathrm{w}$ gospodarce przez tworzenie odrębnych podmiotów gospodarujacych lub w innych formach partycypacji organizacyjnej w podejmowaniu lub wykonywaniu przedsiębiorczości nie prowadzi jednak do zrównania sytuacji tak utworzonych podmiotów z sytuacją osób fizycznych, które tworzą jednostki organizacyjne dla wykonywania działalności gospodarczej, co potwierdza orzecznictwo Trybunału Konstytucyjnego. Problematyka ta będzie rozwinięta w dalszej części opracowania.

Jednostka - osoba fizyczna lub jednostka organizacyjna korzysta w swojej przedsiębiorczości z konstytucyjnie ukształtowanej wolności gospodarczej nie tylko w stosunkach obrotu gospodarczego. Realizuje ona swoje prawo do wolności gospodarczej również w relacjach łączących jednostkę z państwem, które jest zobowiązane chronić wolę przedsiębiorcy zainteresowanego urzeczywistnianiem przysługujacej mu wolności gospodarczej². Pewnym, określonym przejawem tej funkcji ochronnej jest aktywność Trybunału Konstytucyjnego ${ }^{3}$. Został on uprawniony do wykonywania funkcji interwencyjnej na wniosek określonych podmiotów (kontrola abstrakcyjna, skarga konstytucyjna, pytanie prawne sadu). Funkcja ta została jednak skojarzona z działalnościa prawodawcy, która podlega ocenom i interpretacji Trybunału Konstytucyjnego

\footnotetext{
${ }^{1}$ Postanowienie TK z 23 lutego 2005 r., Ts 35/04, OTK ZU 2005, nr 1/B, poz. 26.

${ }^{2}$ M. Szydło, Wolność działalności gospodarczej jako prawo podstawowe, Bydgoszcz-Wrocław 2011, s. 55-56.

${ }^{3}$ Por. K. Wojtyczek, Sadownictwo konstytucyjne w Polsce. Wybrane zagadnienia, Warszawa 2013, s. 85 i n.
} 
przez jej odniesienie do wartości (klauzul) konstytucyjnych. Kontrola Trybunału Konstytucyjnego jest charakteryzowana jako kontrola nad prawem, co eliminuje z zakresu kognicji Trybunału kontrolę „celowości i trafności rozwiązań przyjmowanych przez ustawodawcę"4.

Znaczenie nadane w Konstytucji wolności działalności gospodarczej wyznacza przede wszystkim jej związanie z przedsiębiorczością oraz sytuacja podmiotów przedsiębiorczości w społecznej gospodarce rynkowej, która stanowi podstawę ustroju gospodarczego Polski. Przez odniesienie do społecznej gospodarki rynkowej i nierozerwalną z nią łączność wolność gospodarcza staje się tym samym elementem i funkcją społecznej gospodarki rynkowej. Wspólnie z pozostałymi wartościami społecznej gospodarki rynkowej charakteryzuje zarazem ustrój gospodarczy państwa - „stanowi podstawę ustroju gospodarczego RP"5.

W rozważaniach o konstytucyjnym rozumieniu społecznej gospodarki rynkowej Trybunał Konstytucyjny zwraca uwagę na wyznaczona przez ustrojodawcę rolę władzy publicznej wobec stosunków gospodarki rynkowej. Trybunał uznaje, że ustrojodawca przez konstytucyjne ujęcie społecznej gospodarki rynkowej odrzucił implementację „czysto liberalnego pojmowania ustroju gospodarczego"6. Państwo jest bowiem uprawnione i zobowiazane do wkraczania w stosunki rynkowe, co Trybunał Konstytucyjny charakteryzuje jako ich korygowanie. Celem korygowania jest realizacja potrzeb społecznych ${ }^{7}$.

W konstytucyjnym spojrzeniu na rolę państwa (władz publicznych) kryje się intencja i zamiar ustrojodawcy przekazania władzy publicznej uprawnienia o szczególnym charakterze - decydowania o zasadności (celowości) ingerencji wobec podmiotów stosunków rynkowych. Takie podejście do roli państwa jest uznawane za swego rodzaju „cenę”, którą należy zapłacić za pozbawienie władz publicznych dominującego wpływu na zachowania przedsiębiorców. Celem owej swoistej prerogatywy, której treść kształtuje prawo ingerowania w sytuację podmiotów przedsiębiorczości, jest w szczególności łagodzenie skutków zachowań uczestników gospodarki rynkowej, kierujacych się w wyborach własnym interesem. Państwo staje się wówczas podmiotem współuczestniczacym w stosunkach gospodarki rynkowej, a cele i zadania tej aktywności związane są z aktualnie realizowaną polityką społeczną. Społeczna gospodarka rynkowa tym samym to rynek z jego podmiotami gospodarczymi wolnymi w swoich wyborach oraz państwo, które zachowuje uprawnienie

${ }^{4}$ Wyrok TK z 8 kwietnia 1998 r., K 10/97, OTK ZU 1998, nr 3, poz. 29.

${ }^{5}$ Wyrok TK z 30 stycznia 2001 r., K 17/00, OTK ZU 2001, nr 1, poz. 4.

${ }^{6}$ Wyrok TK z 30 stycznia 2001 r., K 17/00, OTK ZU 2001, nr 1, poz. 4.

${ }^{7}$ K. Kiczka, Funkcje administracji gospodarczej jako przedmiot badań, w: B. Popowska (red.), Funkcje wspótczesnej administracji gospodarczej, Poznań 2006, s. 57. 
do korygowania obiektywnych zjawisk (praw), co nadaje gospodarce rynkowej wymiar społeczny.

Wymiar społeczny gospodarki rynkowej jest zakorzeniony w zasadzie demokratycznego państwa prawnego (art. 2 Konstytucji). Trybunał Konstytucyjny w swoich licznych orzeczeniach odczytywał treść tej zasady przez ujawnienie kryjacych się w niej dyrektyw o charakterze szczególnym i materialnym. Jedna z nich jest zasada sprawiedliwości społecznej. To z treści zasady sprawiedliwości społecznej ustrojodawca wywodzi dialog i współpracę partnerów społecznych oraz wiąże (art. 20 Konstytucji) ten dialog i współpracę ze społeczną gospodarką rynkową i jej partnerami społecznymi, którzy w swoich zachowaniach korzystaja z wolności i autonomii woli, co winno zwłaszcza prowadzić do rozstrzygania spraw spornych w sposób negocjacyjny. Komponentem społecznej gospodarki rynkowej jest zarazem solidarność społeczna. W określeniu tym kryje się nie tylko obowiązek uwzględniania i szanowania praw i wolności innych podmiotów. Solidarność społeczna niesie ze sobą w sytuacji uczestników gospodarki rynku obowiązek poddania się regułom i wynikającym z ich treści obligom, które ograniczają wolność przedsiębiorczości.

Solidarność społeczna jest określeniem i instytucją prawa konstytucyjnego, która ma swój wyraz podmiotowy przez jej odniesienie do podmiotów wolności działalności gospodarczej (przedsiębiorców). Ustrojodawca przyją w interpretacji Trybunału Konstytucyjnego - możliwość ograniczania wolności przede wszystkim w stosunkach wzajemnych między przedsiębiorcami. Solidarność oznacza przyzwolenie na umniejszenia wolności, jeżeli celem tego umniejszenia będzie zapewnienie i poszanowanie wolności innych podmiotów - nie tylko podmiotów stosunków rynkowych ${ }^{8}$. Interes jednostki może bowiem pozostawać $\mathrm{w}$ istotowych zależnościach $\mathrm{z}$ interesami innych jednostek (podmiotów) ${ }^{9}$. Trybunał Konstytucyjny opisał to relacyjne ujęcie sytuacji podmiotów rynkowych oraz innych podmiotów przez ustalenie, „że idee równości społecznej i solidarności wymagaja, aby ciężar kryzysu społecznego obciążał wszystkie warstwy społeczne, a nie dotykał w sposób szczególny tylko niektóre z nich” ${ }^{10}$. Pogląd ten został też wyrażony przez wyróżnienie obowiązku „partycypowania w obciążeniach na rzecz społeczeństwa" ${ }^{11}$.

Trybunał Konstytucyjny rozważa tożsamość konstytucyjną społecznej gospodarki rynkowej również przez zestawianie ze sobą jej elementów treściowych: wolności działalności gospodarczej, własności prywatnej oraz solidarności, dialogu i współpracy partnerów społecznych. Trybunał charakteryzuje społeczna gospodarkę rynkowa w tym wymiarze przez ustalenie relacji między wyróżnionymi przez ustrojodawcę elementami. Kompleksowe i komplementarne przywoływanie tych elementów prowadzi Trybunał Konstytucyjny do ustalenia, że każdy z nich pozostaje w związkach z pozostałymi ${ }^{12}$; wola

\footnotetext{
${ }^{8}$ W. Jakimowicz, Publiczne prawa podmiotowe, Kraków 2002, s. 296-297.

${ }^{9}$ Wyrok WSA z 16 października 2007 r., VI SA/Wa 623/07, Centralna Baza Sąów Administracyjnych.

${ }_{10}$ Wyrok TK z 11 lutego 1992 r., K 14/01, OTK 1992, cz. I, poz. 7.

${ }^{11}$ Wyrok TK z 24 stycznia 2001 r., K 17/00, OTK ZU 2001, nr 1, poz. 4.

12 E. Kosiński, Aspekt prawny wolności gospodarczej, „Kwartalnik Prawa Publicznego” 2003, nr 3, s. 24-26.
} 
ustrojodawcy było tym samym ich ujmowanie w sposób kumulatywny przy charakterystyce społecznej gospodarki rynkowej. Inaczej mówiąc - usunięcie jednej z wartości przynależnych do społecznej gospodarki rynkowej prowadzi do pozbawienia jej tożsamości, co w istocie zmienia model i ustrój gospodarczy państwa.

Miejsce wolności gospodarczej w społecznej gospodarce rynkowej oraz jej treści normatywne widzimy w przedmiocie dyskusji intelektualnych, wspieranych i rozwijanych przez wartości wywodzone z orzecznictwa Trybunału Konstytucyjnego. Poza sporem naukowym w doktrynie publicznego prawa gospodarczego pozostaje przyznawanie wolności gospodarczej szczególnego znaczenia w konstytucyjnym ujęciu sytuacji jednostki: „należy ona do wartości cennych dla jednostki"13. Rozwijanie tej myśli byłoby niestosowne, jeżeli uwzględnimy utrwalone w nauce poglądy, wszechstronnie oświetlające problematykę wolności gospodarczej, w których w zasadzie nie znajdziemy rozbieżności w ujęciu istoty wolności gospodarczej. Takie ujednolicone spojrzenie nie jest już jednak widoczne w szczegółowych analizach i poglądach doktryny oraz trybunalskiego spojrzenia na wolność gospodarczą różnych kategorii uczestników gospodarki rynkowej - o czym dalej.

Trybunał wyróżnia znamienne „cechy wolności gospodarczej”14, kiedy charakteryzuje ja jako urzeczywistniane w aktach woli prawo do podjęcia oraz określenia przedmiotu działalności gospodarczej, jej prowadzenia w wybranej formie oraz zakończenia ${ }^{15}$. Wskazałem wyżej, że wolność gospodarcza jest wartością o szczególnej istocie. Jej źródłem jest bowiem wolność człowieka ${ }^{16}$, która ma charakter obiektywny i niezależny od woli władz publicznych. Związanie wolności gospodarczej z wolnością człowieka nadaje jej ten sam wyraz niezależności i obiektywności, który istotowo przynależy do wolności osoby ludzkiej. Wolność gospodarcza nie jest wartością kreowaną i nadawaną z woli ustrojodawcy (władz publicznych); raczej można mówić, że ustrojodawca sankcjonuje wolność gospodarczą przez użycie pojęć i instytucji właściwych dla stanowienia prawa i z użyciem języka prawnego, przyjmowanego dla uznania i potwierdzenia obecności wolności gospodarczej w życiu gospodarczym ${ }^{17}$. Powiązanie wolności gospodarczej z konstytucyjnie ujętym statusem osoby ludzkiej i przyrodzoną do niej wolnością nadaje wolności gospodarczej jako prawu podmiotowemu jednostki do niej ${ }^{18}$ wyraz prawa konstytucyjnie chronionego. Konsekwencją konstytucyjnego ujęcia wolności gospodarczej jest uznanie prawa do niej za prawo podmiotowe publiczne ${ }^{19}$.

${ }^{13}$ K. Wojtyczek, Horyzontalny wymiar praw człowieka zagwarantowany $w$ Konstytucji RP, „Kwartalnik Prawa Prywatnego” 1999, nr 2, s. 27.

14 Wyrok TK z 5 kwietnia 2001 r., P 26/09, OTK ZU 2011, nr 3/A, poz. 18.

15 Wyrok TK z 29 kwietnia 2003 r., SK 24/02, OTK ZU 2003, nr 4/A, poz. 33.

${ }_{16}$ K. Wojtyczek, Granice ingerencji ustawodawczej $w$ sferę praw człowieka $w$ Konstytucji RP, Kraków 1999, s. 37.

17 Por. wyrok TK z 14 czerwca 2004 r., SK 21/03, OTK ZU 2004, nr 6/A, poz. 45.

18 M. Szydło, op. cit., s. 24.

${ }^{19}$ K. Kiczka, Administracyjnoprawne środki ksztattowania sytuacji prawnej przedsiębiorców, w: L. Kieres (red.), Administracyjne prawo gospodarcze, Wrocław 2009, s. 364. 
Wyróżnione wyżej prawo państwa do korygowania stosunków rynkowych, co jest istotną cechą społecznej gospodarki rynkowej, kierowało uwagę Trybunału Konstytucyjnego na relacje podmiotów obrotu gospodarczego z władzami publicznymi. Potwierdzenie wolności gospodarczej jako zasady konstytucyjnej i konstytucyjnego prawa podmiotowego wyrażają wywodzone z niej czastkowe i prawem określone zakazy ${ }^{20}$ ingerencji w sytuacje prawne, kształtowane przez przedsiębiorczość - np. przez ograniczanie dostępu osobom zagranicznym (przedsiębiorcom zagranicznym) do rynku krajowego. Ingerencja taka stanowi bowiem w skutkach naruszenie szczególnej wartości, jaką jest wolność gospodarcza ujęta jako konstytucyjne prawo wolnościowe ${ }^{21}$.

Ustrojodawca zarazem nie absolutyzuje wolności gospodarczej (swobody działalności gospodarczej) ${ }^{22}$, co przejawiałoby się w sytuacji władz publicznych w ustanowieniu generalnego zakazu jej naruszania bez możliwości odstępstw od niego w sytuacjach szczególnych. Działalność gospodarcza może podlegać ingerencjom ze strony tych władz. Działania korygujace władz publicznych, podejmowane wobec podmiotów działalności gospodarczej, nie powinny jednak prowadzić do nieusprawiedliwionego i nadmiernego zakłócenia działalności gospodarczej ${ }^{23}$. Tak ujęty rygor rządzący inicjatywami władz publicznych wymagał wyróżnienia w Konstytucji przesłanek, które usprawiedliwiaja dopuszczalną ingerencję w wolność gospodarczą (art. 22). W treści art. 22 Konstytucji znajdujemy tym samym potwierdzenie za postanowieniem art. 20 (statuowanie $)^{24}$ zasady wolności gospodarczej. Natomiast analiza treści przesłanek usprawiedliwiajacych ingerencję w wolność gospodarcza, weryfikowana w orzecznictwie Trybunału Konstytucyjnego na tle treści art. 20, ujawnia wolność gospodarczą jako zasadę ustrojową (zasada ustroju gospodarczego) ${ }^{25}$ oraz prowadzi do wiązania z nią szczególnego, konstytucyjnego prawa podmiotowego, jakim jest wolność gospodarcza (prawo do wolności gospodarczej) ${ }^{26}$.

\section{IV}

Ustrojodawca przyjął szczególne i odrębne dla wolności gospodarczej warunki jej ograniczenia (art. 22). Trybunał konsekwentnie konfrontuje te specjalne ujęcia z ograniczeniami, wspólnymi dla wszystkich podstawowych wolności konstytucyjnych ${ }^{27}$. Dla ustalenia stanowiska ustrojodawcy maja zwłaszcza znaczenie relacje między przesłankami usprawiedliwiającymi ograniczanie wolności człowieka, wyróżnionymi w art. 31 ust. 3 Konstytucji, i prze-

${ }^{20}$ R. Sowiński, Wolność $i$ ustawowa swoboda działalności gospodarczej, Wrocław 2009, s. 183 i n.

${ }^{21}$ K. Klecha, Wolność działalności gospodarczej $w$ Konstytucji RP, Warszawa 2009, s. 52.

${ }^{22}$ Wyrok SN z 9 sierpnia 2006 r., III SK 6/06.

${ }^{23}$ Wyrok TK z 10 kwietnia 2001 r., U 7/00, OTK ZU 2001, nr 3, poz. 56.

${ }^{24}$ Wyrok TK z 23 czerwca 1999 r., K 30/98, OTK ZU 1999, nr 5, poz. 101.

25 Wyrok TK z 21 kwietnia 2004 r., K 33/03, OTK ZU 2004, nr 4/A, poz. 31.

${ }^{26}$ Wyrok TK z 13 października 2010 r., Kp 1/09, OTK ZU 2010, nr 8/A, poz. 74.

27 Wyrok TK z 13 października 2010 r., Kp 1/09, OTK ZU 2010, nr 8/A, poz. 74. 
słanką „ważnego interesu publicznego” (art. 22 Konstytucji), która uzasadnia ograniczanie wolności gospodarczej. Analiza relacji, jakie wyznaczono między tymi wartościami konstytucyjnymi, inspiruje Trybunał do ustalenia, że ustawodawca jest uprawniony do wykraczania poza katalog przesłanek z art. 31 ust. 3 przy ingerencji w wolność gospodarczą przedsiębiorców. Tym samym może on kierować się także innymi wartościami, które mają usprawiedliwiać ingerencję w wolność gospodarczą jej podmiotów. Upoważnienie udzielone ustawodawcy do ograniczenia wolności gospodarczej przez przyjmowanie przesłanek swoistych, które nie mieszczą się w katalogu wartości ujętych w art. 31 ust. 3 Konstytucji, oznacza, że wolność gospodarcza może podlegać ograniczeniom w szerszym zakresie w porównaniu z innymi wolnościami konstytucyjnymi.

Stanowisko o możliwości kreowania przez ustawodawcę szczególnych przesłanek usprawiedliwiających ograniczanie wolności gospodarczej wspiera zarazem pogląd o związaniu ich z kategorią ważnego interesu publicznego, co oznacza, że przesłanka determinująca (usprawiedliwiająca) ingerencję w wolność gospodarczą nie może mieć charakteru bagatelnego. Ingerencja taka winna zarazem być motywowana potrzebą ochrony innych norm lub wartości konstytucyjnych. Cel i intencja stanowiska ustawodawcy w takich sytuacjach sa poddawane specjalnym i odrębnym weryfikacjom. Mowa tutaj o „zwiększonym rygoryzmie dotyczącym ustawowej regulacji ograniczenia wolności działalności gospodarczej”"28. Rygoryzm ten jest konfrontowany ze szczególna odpowiedzialnościa państwa za funkcjonowanie wolnościowych „mechanizmów gospodarczych". Interesem państwa wyznaczonym konstytucyjnie jest zwłaszcza korygowanie niekorzystnych dla państwa (społeczeństwa) skutków mechanizmów wolnorynkowych ${ }^{29}$.

W interpretacjach wolności gospodarczej na tle art. 22 Konstytucji wskazuje się nie tylko na przesłanki tej ingerencji (ochrona ważnego interesu publicznego - przesłanka materialna, oraz forma - droga ustawy) ${ }^{30}$. Gwarancja ochrony praw podmiotowych wywodzonych z wolności gospodarczej jest także zaliczenie przesłanek ingerencji ustawodawcy do pola o „nieprzekraczalnych granicach" 31 . Treścią tej gwarancji jest oblig, odnoszony do władz publicznych, kierowania się w inicjatywach ograniczania wolności gospodarczej dyrektywami ujętymi w treści art. 22. Odbiciem normatywnym tak usprawiedliwionej ingerencji po stronie przedsiębiorcy sa granice wolności przedsiębiorczości ${ }^{32}$. Wyznacza je prawo podmiotowe przedsiębiorcy do ochrony wolności w relacjach z władzami publicznymi, jeżeli wykroczą przeciwko przesłankom ingerencji, wyróżnionym w art. $22^{33}$.

${ }^{28}$ Wyrok TK z 13 października 2010 r., Kp 1/09, OTK ZU 2010, nr 8/A, poz. 74.

${ }^{29}$ Wyrok TK z 8 kwietnia 1998 r., K 10/97, OTK ZU 1998, nr 3, poz. 29.

${ }^{30}$ Wyrok TK z 13 października 2010 r., Kp 1/09, OTK ZU 2010, nr 8/A, poz. 74.

${ }^{31}$ K. Kiczka, Administracyjnoprawne środki kształtowania sytuacji prawnej przedsiębiorców, s. 365 .

${ }^{32}$ K. Wojtyczek, Granice ingerencji ustawodawczej $w$ sfere praw człowieka w Konstytucji RP, s. 36 .

${ }^{33}$ Wyrok TK z 5 kwietnia 2011 r., P 26/09, OTK ZU 2011, nr 3/A, poz. 18. 
Prymat ochrony interesu publicznego wywodzony jest z rangi wartości, które kształtują jego treść. Przypisywanie do interesu publicznego wartości, zróżnicowanych znaczeniowo co do swojej doniosłości, pozwala na wyróżnienie pośród nich takich, które usprawiedliwiają uznanie interesu publicznego za ważny. Podlega on zwłaszcza ochronie, jeżeli za ważnym interesem publicznym kryją się „powszechnie uznawane wartości”34.

Wolność gospodarcza jest wartością szczególną i zarazem ma charakter powszechny. Mieści się bowiem - jak to wcześniej wspomniałem - w wolności człowieka jako wartości powszechnej; jest jej treścia, która wypełnia wolność powszechną razem z innymi kategoriami praw i wolności konstytucyjnych ${ }^{35}$. Powszechność wartości konstytucyjnie uznanych, których doniosłość potwierdzają wywodzone $\mathrm{z}$ nich i chronione prawa podmiotowe, ma to znaczenie, że odstępstwo od owej powszechności przez pozbawienie lub ograniczenie niektórych podmiotów w prawie do wolności winno być usprawiedliwione względami konstytucyjnie ujętymi i nie może mieć charakteru dyskryminującego.

Granice uprawnień do ingerencji w wolność gospodarczą wyznacza także wymóg „konieczności” ingerencji ${ }^{36}$. Trybunał Konstytucyjny charakteryzuje tę konieczność przez odniesienie do niej cechy „obiektywnej niezbędności” ${ }^{37}$, ale to w sferze uprawnień ustawodawcy leży interpretacja tak charakteryzowanej konieczności. W świetle tak ujętej sytuacji ustawodawcy należy interpretować przywołany wyżej pogląd, że ustawodawca został uprawniony do kształtowania (uznawania) przesłanek ingerencji w wolność gospodarcza, które nie zostały wyróżnione w art. 31 ust. 3 Konstytucji. Ograniczenie wolności determinowane koniecznością ingerencji w prawa wolnościowe winno podlegać w każdej sytuacji usprawiedliwieniu przez wskazanie na okoliczności, które uzasadniają niezbędność ochrony interesu publicznego. Za ograniczeniem wolności winny stać co najmniej wartości o randze przypisywanej do przesłanek wskazanych w art. 31 ust. 3 . W kategorii ważnego interesu publicznego mieszczą się także inne wartości, ustalone z uwzględnieniem art. 22 Konstytucji ${ }^{38}$. Wybór tych wartości podlega kontroli ze strony Trybunału Konstytucyjnego przez weryfikację stopnia ich doniosłości i obiektywnego charakteru. Weryfikacja ta jest prowadzona na tle i w związku z wartościami, które promuje i chroni Konstytucja. Przesłankom usprawiedliwiającym ingerencję w prawo do wolności gospodarczej niewątpliwie nie przydają charakteru konieczności (doniosłości) żądania (postulaty) grup społecznych ${ }^{39}$, nawet wówczas gdy ich autorytet jest społecznie akceptowany czy też posiadają zdolności zajmowania uwagi opinii publicznej czy środowisk opiniotwórczych własnymi i partykularnymi interesami czy własną aktywnościa, jeżeli żądania te nie zostały wywiedzione z wartości konstytucyjnych.

\footnotetext{
${ }^{34}$ Wyrok TK z 14 czerwca 2004 r., SK 21/03, OTK ZU 2004, nr 6/A, poz. 56.

35 Wyrok WSA w Warszawie z 16 października 2007 r., VI SA/Wa 623/07, Centralna Baza Orzeczeń Saców Administracyjnych.

${ }^{36}$ Wyrok TK z 7 maja 2001 r., K 19/00, OTK ZU 2001, nr 4, poz. 82.

37 Wyrok TK z 7 maja 2001 r., K 19/00, OTK ZU 2001, nr 4, poz. 82.

38 Wyrok TK z 19 stycznia 2010 r., SK 35/08, OTK ZU 2010, nr 1/A, poz. 2.

${ }^{39}$ Wyrok TK z 19 stycznia 2010 r., SK 35/08, OTK ZU 2010, nr 1/A, poz. 2.
} 
Oczywistość ograniczania wolności gospodarczej, o której mówi Trybunał Konstytucyjny ${ }^{40}$, powinna stanowić co najmniej standard odnoszony do państw demokratycznych. Zadaniem ustawodawcy jest nie tylko wskazanie na tak charakteryzowaną oczywistość jako treść konieczności ingerencji w prawo do wolności gospodarczej, a przez to w prawa podmiotowe wywodzone z wolności przedsiębiorczości. Konieczne jest także uzasadnienie ingerencji przez podanie jej konkretnych motywów w sytuacjach owej oczywistości. Usprawiedliwienie ingerencji przez związanie jej z przesłanką oczywistości bez wyjaśnienia treści owej oczywistości w istocie znosi możliwość weryfikacji celowości przyjętych remediów. Takie lakoniczne i oszczędne usprawiedliwienie ingerencji w wolność gospodarczą może prowadzić do sytuacji określanej jako tworzenie przez władze publiczne „prawa dla siebie” przez samodzielne przyjmowanie przez te władze przesłanek, które mają usprawiedliwiać ich aktywność. Organy te tworza podstawy własnej działalności, kiedy ich aktywność jest oceniana i weryfikowana z uwzględnieniem wartości przyjętych przez nie dla uzasadnienia podjętych działań.

Kategoria „ważnego interesu publicznego” jest jedną z dwóch przesłanek, które uzasadniają ingerencję w prawo do wolności gospodarczej (art. 22 Konstytucji). Materialny jej charakter tworzy treść wiązana z interesem publicznym oraz jego doniosła istota (ważny charakter) ${ }^{41}$. Interes publiczny wiążemy z dobrem wspólnym, które ze względu na swoją wartość (doniosłość usprawiedliwiona względami publicznymi) podlega szczególnej ochronie. Znaczenie tego stanowiska znajduje uzasadnienie w art. 1 Konstytucji, który stanowi o szczególnej kategorii dobra wspólnego, odniesionego do wszystkich obywateli, jakim jest Rzeczpospolita ${ }^{42}$. Ingerencję w wolność gospodarczą wyznacza działanie będące przejawem woli władzy, która ingeruje w wyniku zidentyfikowania ${ }^{43}$ (łączenia) klauzuli generalnej (konstytucyjnej) „ważnego interesu publicznego" z wyróżnioną w ustawie i normatywnie ujętą sytuacją przedsiębiorców. Identyfikowanie w takim przypadku oznacza zarazem weryfikowanie na tle konkretnych zdarzeń, zaliczanych do podejmowania i wykonywania działalności gospodarczej, potrzeby przyjęcia odpowiedniej regulacji ustawowej z zamiarem ochrony ważnego interesu publicznego.

Wyróżnienie i określenie treści interesu publicznego, chronionego przez ingerencję ustawową w wolność gospodarcza, wymaga spełnienia odpowiednich rygorów. Trybunał Konstytucyjny wskazał na nie w drodze zestawienia i interpretacji postanowień Konstytucji, co pozwala na wyodrębnienie innych niż wolność gospodarcza wartości, które podlegają ochronie konstytucyjnej -

\footnotetext{
${ }^{40}$ Wyrok TK z 23 czerwca 1999 r., K 30/98, OTK ZU 1999, nr 5, poz. 101.

41 Wyrok TK z 13 października 2010 r., Kp 1/09, OTK ZU 2010, nr 8/A, poz. 74.

42 Wyrok TK z 30 stycznia 2001 r., K 17/00, OTK ZU 2001, nr 1, poz. 4.

43 Wyrok TK z 13 października 2010 r., Kp 1/09, OTK ZU 2010, nr 8/A, poz. 74.
} 
i tym samym wspieranie koncepcji demokratycznego państwa prawnego ${ }^{44}$. Ten proces swego rodzaju „ważenia” interesu publicznego w celu wyznaczenia stopnia jego doniosłości w konfrontacji z wolnością gospodarczą prowadzi w pewnych sytuacjach do uznawania przez ustawodawcę potrzeby szczególnej jego ochrony także przez ograniczanie prawa do wolności gospodarczej. W istocie więc konieczność interwencji uzasadniona „ważnością interesu publicznego" może wyzwalać reakcję ustawodawcy przez ograniczenie wolności gospodarczej, jeżeli inne możliwości i środki ochrony interesu publicznego okazują się niewystarczające.

Zakaz nadmiernego ingerowania wymagał ustalenia i charakterystyki środków owej ingerencji, co prowadziło do wskazania na powinność mierzenia skutków projektowanych czy podejmowanych ograniczeń (remediów) wobec zamiaru osiagnięcia określonego celu - np. ochrony konkurencji ${ }^{45}$. Cel taki zwykle daje się uzyskać przez naruszenie innych interesów. Trybunał Konstytucyjny odnosi do takiej reakcji miarę adekwatności, co oznacza obowiązek analizy skutków projektowanej regulacji dla „wagi interesów naruszanych” ${ }^{46}$ i wiąże ją ze środkiem, który zapewnia ochronę ważnego interesu publicznego ${ }^{47}$. Trybunał Konstytucyjny wskazał zarazem na wymogi ${ }^{48}$, którymi winien kierować się organ władzy publicznej, kiedy wybiera środki właściwe do koniecznej ingerencji: „1) środki zastosowane przez prawodawcę muszą być w stanie doprowadzić do zamierzonych celów; 2) muszą one być niezbędne do ochrony interesu, z którym są powiązane, 3) ich efekty muszą pozostawać w proporcji do ciężarów nakładanych na obywatela”. Reguły te - ujęte kumulatywnie - kształtują treść zasady proporcjonalności. Każda sytuacja wymaga tym samym indywidualnego spojrzenia na konieczność ograniczenia wolności gospodarczej. Władza ingerująca jest zobligowana do takiego użycia środków w celu ingerencji w wolność gospodarcza, by ograniczenie to nie wykraczało poza miarę konieczności (niezbędności) do ochrony interesu publicznego, którego treść wyznaczają wartości wskazane w Konstytucji lub w ustawach.

Te dwa usprawiedliwienia (adekwatność oraz właściwa ocena skutków ingerencji dla innych praw wolnościowych, chronionych konstytucyjnie) w istocie prowadzą do rygoryzowania ustawodawcy, który ograniczając wolność gospodarcza, przede wszystkim nie powinien wkraczać na pole innych „wartości, zasad lub norm konstytucyjnych" ${ }^{49}$, chyba że dla ochrony ważnego interesu publicznego jest niezbędne ograniczenie wolności gospodarczej jako jednej z wolności konstytucyjnych ${ }^{50}$. Wskazanie na wymóg adekwatności w istocie prowadzi także do możliwości weryfikowania działań władz publicznych wobec podmiotów działalności gospodarczej jako bezprawnych (wadliwych) w sytuacji użycia środków nieadekwatnych w znaczeniu ujętym wyżej.

\footnotetext{
${ }^{44}$ Wyrok TK z 17 grudnia 2003 r., SK 15/02, OTK ZU 2003, nr 9/A, poz. 103.

45 M. Szydło, op. cit., s. 61 i n.

46 Wyrok TK z 21 kwietnia 2004 r., K 33/03, OTK ZU 2004, nr 4/A, poz. 31.

${ }^{47}$ Wyrok TK z 29 kwietnia 2003 r., SK 24/02, OTK ZU 2003, nr 4/A, poz. 33.

48 Wyrok TK z 21 kwietnia 2004 r., K 33/03, OTK ZU 2004, nr 4/A, poz. 31.

49 Wyrok TK z 13 października 2010 r., Kp 1/09, OTK ZU 2010, nr 8/A, poz. 74

${ }^{50}$ Wyrok TK z 8 kwietnia 1998 r., K 10/97, OTK ZU 1998, nr 3, poz. 29.
} 
Aktywność ustawodawcy może zawierać się w podejmowaniu „na próbę” działań ingerujących w prawa i wolności konstytucyjne oraz składaniu obietnic bez pokrycia ${ }^{51}$ zmniejszania ich negatywnych skutków lub zapowiadaniu przyjęcia innych regulacji prawnych łagodzących dotkliwość ingerencji, co także nie zostaje spełnione. Podlega ona co do zasady ocenie negatywnej ${ }^{52}$ przez odniesienie do takich aktów zarzutu niezgodności z porządkiem konstytucyjnym. „Niedopuszczalne jest, aby najpierw namawiać obywateli do pewnego rozwiązania, a następnie traktować osoby, które „dały się na to nabrać”, gorzej niż osoby, które zignorowały zachęty ustawodawcy” ${ }^{53}$. Pogląd ten podlega już jednak weryfikacji, jeżeli zostaje odniesiony do techniki legislacyjnej, kiedy ustawodawca posługuje się w celach regulacyjnych wyrażeniami (pojęciami) lub zwrotami niedookreślonymi. Zasadą jest wprawdzie poszanowanie wymogu jednoznacznego i precyzyjnego ujęcia w przepisie woli ustawodawcy czy też wyrażenie w podobny sposób przyznania władzom publicznym uprawnienia do ingerowania w prawa wolnościowe. Posługiwanie się pojęciami nieostrymi ${ }^{54}$ należy zarazem do kategorii usprawiedliwionego wyjątku od wymogu określoności regulacji prawnych, motywowanego koniecznością ochrony interesu publicznego.

Dopuszczalna konstytucyjnie koncesja na rzecz zwrotów nieostrych zaznacza swoją obecność w sposób szczególny w regulacjach wolności gospodarczej55. „Często bowiem skonstruowanie określonej normy prawnej za ich pomoca stanowi jedyne rozsądne wyjście" 56 . Stosunki rynkowe charakteryzuje swoista tożsamość, determinowana obiektywnymi zjawiskami rynkowymi o własnej specyfice i dużej zmienności. Tego rodzaju tożsamość przedsiębiorczości została uznana przez Trybunał Konstytucyjny. W swoim orzecznictwie wskazał na nią jako usprawiedliwienie normatywnego ujmowania przedsiębiorczości w stosunkach między jej podmiotami (przedsiębiorcy) i władzami publicznymi przez przyjmowanie pojęć nieostrych w regulacjach prawnych wolności gospodarczej. Zasadność posługiwania się nimi w legislacji podlega jednak ocenom, w których należy uwzględniać ogólne reguły odnoszone przez ustrojodawcę do zasad ochrony wolności gospodarczej. Niewątpliwie takim usprawiedliwieniem nie jest stan dominującego posługiwania się pojęciami nieostrymi przy kształtowaniu przesłanek usprawiedliwionej ingerencji w prawo podmiotowe do wolności gospodarczej - kosztem precyzji i jednoznaczności sformułowań, określeń czy terminów właściwych poprawnemu językowi prawnemu.

Zgłoszenie podobnego w treści postulatu uzasadnia stanowisko Trybunału Konstytucyjnego osadzone w treści art. 22 Konstytucji, w części stanowiącej o dopuszczalności ograniczenia wolności działalności gospodarczej wyłącznie

51 Wyrok TK z 3 grudnia 1996 r., K 25/95, OTK ZU 1996, nr 6, poz. 52.

52 „Nie do pogodzenia z zasadą zaufania do państwa jest wprowadzenie obywateli w błąd w wyniku składania przez przedstawicieli władzy państwowej zapowiedzi, dotyczących przyszłego stanu prawnego, a następnie niedotrzymywanie tych zapowiedzi” - wyrok NSA z 8 czerwca 1992 r., III SA 241/92, Centralna Baza Orzeczeń Sądów Administracyjnych.

${ }^{53}$ Wyrok TK z 26 stycznia 2010 r., K 9/08, OTK ZU 2010, nr 1/A, poz. 4.

${ }_{54}$ Wyrok TK z 17 października 2000 r., SK 5/99, OTK ZU 2000, nr 7, poz. 254.

55 Wyrok TK z 26 marca 2007 r., K 29/06, OTK ZU 2007, nr 3/A.

${ }^{56}$ Uchwała TK z 6 listopada 1991 r., W/2/91, OTK 1995, t. 3, poz. 30. 
w formie ustawowej. W świetle stanowiska Trybunału ustawowa forma ograniczania wolności gospodarczej została w Konstytucji odniesiona do ingerencji w prawo podmiotowe do wolności przede wszystkim w sytuacjach ujętych w art. 31 ust. 3. Przesłanki tej ingerencji moga jednak wyznaczać także ustawy, o czym była mowa wyżej. Oznacza to przyzwolenie, udzielone ustawodawcy, na wyróżnianie „własnych” przesłanek, które wprawdzie nie mieszczą się w art. 31 ust. 3, ale usprawiedliwiaja przyjmowanie regulacji w formie ustawy, prowadzących do ograniczenia wolności działalności gospodarczej. Trybunał Konstytucyjny dokonał zarazem interpretacji przesłanek warunkujących przyjmowanie w formie rozporządzenia regulacji konkretyzujacych rozwiązania ustawowe w sprawach przedsiębiorczości. Dokonał w tym celu swego rodzaju adaptacji wyłożonych wyżej warunków i przesłanek sankcjonujacych przyjmowanie regulacji, które ograniczają wolność gospodarcza.

Konstytucyjne ujęcie wymogu przyjmowania ustawowej formy ograniczania wolności gospodarczej stwarza władzom publicznym warunki szerszej ingerencji w wolność gospodarczą wobec możliwości ograniczania innych praw i wolności ujętych w Konstytucji ${ }^{57}$. Konsekwencja powyżej opisanego stanowiska ustrojodawcy, które zostało utrwalone w orzecznictwie Trybunału Konstytucyjnego, jest zarazem wskazanie na rolę rozporządzenia w regulacjach przedsiębiorczości. Trybunał dopuszcza możliwość przyznania formie rozporządzenia roli szczególnej przy wyznaczaniu sytuacji przedsiębiorcy przez ograniczenie jego prawa podmiotowego do wolności gospodarczej. W przypadkach takiej ingerencji, uzasadnionej przesłankami, które nie mieszczą się w katalogu ujętym w treści art. 31 ust. 3 Konstytucji, a wyróżnionymi w ustawach ze względu na ważny interes publiczny (art. 22 Konstytucji), ustawodawca może przekazać do właściwości regulacyjnej rozporządzenia zagadnienia szczególne, które mają istotne znaczenie dla wyznaczenia granic wolności gospodarczej i instrumentów jej ochrony (np. procedury podejmowania aktów reglamentacji gospodarczej lub przyjmowania w ich treści instytucji swoistych, tożsamych dla relacji między przedsiębiorcami a władzami publicznymi).

Poza sfera przedmiotową regulacji rozporządzenia pozostaje wskazanie na przesłanki ingerencji w prawo do wolności gospodarczej: „ustawa musi samodzielnie określać zasadnicze elementy regulacji prawnej” ${ }^{58}$, a rozporządzenie nie może ich modyfikować59. Ustawa nie może zarazem wyróżniać tych elementów w sposób blankietowy, co wskazywałoby na przekazanie do właściwości regulacyjnej rozporządzeń zdolności do ich katalogowania. Oznaczałoby to bowiem w istocie przekazanie władzom publicznym uprawnienia do ustalania zakresu wolności gospodarczej ${ }^{60}$.

Zarysowane wyżej w elementach podstawowych stanowisko trybunalskie inspiruje do pytań i ocen na temat treściowych związków między ustawowa formą ograniczania wolności działalności gospodarczej a aktami wykonawczymi - zwłaszcza rozporządzeniami. Wracamy w tak postawionym wyzwaniu

\footnotetext{
${ }_{57}$ Wyrok TK z 13 października 2010 r., Kp 1/09, OTK ZU 2010, nr 8/A, poz. 74

58 Wyrok TK z 12 stycznia 2000 r., P 11/98, OTK ZU 2000, nr 1, poz. 3.

59 Wyrok TK z 5 czerwca 2001 r., K 18/00, OTK ZU 2001, nr 5, poz. 118.

${ }^{60}$ Wyrok TK z 12 stycznia 2000 r., P 11/98, OTK ZU 2000, nr 1, poz. 3.
} 
badawczym do dawnej i - w pewnym sensie - starej koncepcji analizy prawa właściwego dla podmiotów działalności gospodarczej w stosunkach z władzami publicznymi. W tamtych badaniach ich osią było zwłaszcza położenie państwowych (publicznych) jednostek gospodarczych wobec organów zwierzchnich. Położenie to wyznaczały treści trwałych więzi organizacyjnych między przedsiębiorstwami lub innymi podmiotami gospodarczymi a organami administracji państwowej.

Współcześnie - w warunkach gospodarki rynkowej - ustawodawca przejął uprawnienia regulatora relacji między przedsiębiorcami a władzami publicznymi. Poluzowanie rygorów, które rządzą stanowieniem prawa podustawowego, obowiązującego $\mathrm{w}$ sytuacji przedsiębiorcy wobec władz publicznych w porównaniu ze stanowieniem prawa o przesłankach ingerencji tych władz w konstytucyjne wolności obywateli (człowieka), może prowadzić do efektów niezamierzonych przez ustrojodawcę oraz Trybunał Konstytucyjny. Wydaje się celowe poddanie weryfikacji stanowiska trybunalskiego na tle i z uwzględnieniem praktyki stanowienia prawa przedsiębiorczości przez administracyjne władze publiczne. W analizach podustawowych form działania władz ważne zwłaszcza byłoby poddanie ocenom przesłanek, które kształtują treść upoważnień do ingerencji w formie aktów indywidualnych w wolność gospodarczą przedsiębiorców, jeżeli przesłanki te wyznaczają w istocie granice ingerencji w wolność gospodarcza.

\section{VI}

Prowadzenie działalności gospodarczej przez przedsiębiorcę w stosunkach obrotu rynkowego jest istotowo zwiazane $\mathrm{z}$ wykonywaniem praw majątkowych, pośród których szczególne znaczenie dla przedsiębiorcy ma własność. Własność podlega ochronie prawnej, a stopień i środki tej ochrony są co do zasady niezależne od podmiotu własności. Ustrojodawca wyróżnia zarazem w Konstytucji sytuacje, które pokazują na granice swobody wykonywania prawa własności i innych praw majątkowych w szczególnych sytuacjach, czy też zakreśla je odrębnie wobec mienia publicznego (art. 216 ust. 2 Konstytucji). Trybunał wywodzi z postanowienia art. 216 ust. 2 uprawnienie ustawodawcy „do bardzo głębokiej ingerencji ustawodawczej w działalność gospodarcza państwowych osób prawnych" ${ }^{61}$. Z kolei w orzecznictwie w sprawach danin publicznych Trybunał przyjął, że zobowiązywanie do określonych ciężarów finansowych nie może być uznawane za ograniczanie własności (art. 64 ust. 3 Konstytucji). Nie każda bowiem zmiana w sytuacji majątkowej oznacza ograniczenie własności jego podmiotu ${ }^{62}$. W poglądzie tym znajduje wsparcie inne spostrzeżenie o tendencji różnicowania sytuacji majątkowej „sektora publicznego i sektora prywatnego w gospodarce"63.

${ }^{61}$ Wyrok TK z 7 maja 2001 r., K 19/00, OTK ZU 2001, nr 4, poz. 82.

${ }^{62}$ Wyrok TK z 30 stycznia 2001 r., K 17/00, OTK ZU 2001, nr 1, poz. 4; też - co do majątku komunalnego: wyrok TK z 9 grudnia 2008 r., K 61/07, OTK ZU 2008, nr 10/A, poz. 174.

${ }^{63}$ Wyrok TK z 7 maja 2001 r., K 19/00, OTK ZU 2001, nr 4, poz. 82. 
Konceptualizacja miejsca własności publicznej w stosunkach obrotu gospodarczego (,fachowość, podporządkowanie regułom opłacalności i zysku lub zasadzie racjonalnego gospodarowania, działanie na własny rachunek, powtarzalność działań oraz uczestnictwo w obrocie gospodarczym" jako przejawy działalności gospodarczej) ${ }^{64}$ prowadzi Trybunał Konstytucyjny do wyróżnienia pośród zadań państwa dwóch kategorii odpowiedzialności wobec gospodarki rynkowej ujętych w regulacjach Konstytucji. Sektor publiczny i jego podmioty wyróżniaja przede wszystkim konstytucyjne i ustawowe zadania, charakteryzowane jako zadania publiczne (społeczne). Państwo odpowiada (piecza) za przestrzeganie zasad gospodarki rynkowej przez jej podmioty (przedsiębiorcy prywatni). W tym zakresie w odpowiedzialności państwa mieszczą się zwłaszcza zadania, które są realizowane w celu pobudzania aktywności podmiotów prywatnych w stosunkach gospodarki rynkowej czy odnoszące się do zasad jej wykonywania. W treści odpowiedzialności mieści się zarazem obowiązek poszanowania uprawnień tych jednostek, którym przysługuje prawo podmiotowe do wolności gospodarczej. Schematycznie można w tym miejscu wspomnieć o aktywności władz publicznych, zaliczanej do sfery regulacyjnej czy kontroli wobec przedsiębiorców. Ta sfera działalności podmiotów publicznych wobec rynku stanowi uzupełnienie i wspomaganie działań właściwych podmiotów, charakteryzujących przedsiębiorczośćc ${ }^{65}$. Szczególną sytuację tych władz w gospodarce wyznaczają w istocie działania (uprawnienia i kompetencje), które wyżej charakteryzowałem jako korygowanie stosunków gospodarki rynkowej dla ochrony godności człowieka ${ }^{66}$.

Tak określona rola państwa wyklucza możliwości przyznawania władzom publicznym szczególnej odpowiedzialności i pieczy wobec samych siebie. Państwo i jego instytucje nie zostały uprawnione do formułowania roszczeń o ochronę praw, podobnych do praw przysługującym podmiotom prywatnym, a wywodzonych z wolności gospodarczej. Sytuacja taka prowadziłaby bowiem do skupiania w gestii podmiotów (władz) publicznych, gdy są uprawnione do podejmowania i wykonywania działalności gospodarczej, prawa do ochrony wolności działalności gospodarczej w stosunkach z podmiotami prywatnymi poddanymi pieczy władz publicznych. Tymczasem dla gospodarki rynkowej istotne są: niedyskryminacja i równe traktowanie jako przesłanki swobodnej konkurencyjności ${ }^{67}$. Władze publiczne zostały zobowiązane przede wszystkim do troski o przestrzeganie konstytucyjnych wymogów kształtujących wolność przedsiębiorczości podmiotów prywatnych.

Działalność gospodarcza państwa jest wprawdzie dozwolona i akceptowana w społecznej gospodarce rynkowej, ale ustawodawca jest zarazem uprawniony do uznania, że obecność sektora publicznego w niektórych dziedzinach aktywności gospodarczej jest ważna dla ochrony (realizacji) interesu publicznego. Kategoria usprawiedliwionych względów ochrony interesu publicznego, któ-

${ }^{64}$ Postanowienie SN z 19 października 1999 r., III CZ 112/99, OSNC 2000, nr 4, poz. 78, OSP 2000, nr 10, poz. 143.

65 Wyrok TK z 7 maja 2001 r., K 19/00, OTK ZU 2001, nr 4, poz. 82.

${ }^{66}$ Wyrok TK z 8 kwietnia 1998 r., K 10/97, OTK ZU 1998, nr 3/A, poz. 29.

67 Wyrok z 7 maja 2001 r., K 19/00, OTK ZU 2001, nr 4, poz. 82. 
ra uzasadnia wyróżnienie na rynku usług świadczonych w ogólnym interesie publicznym (społecznym), jest tutaj szczególnym przykładem motywujaccym wykonywanie przez podmioty publiczne działalności gospodarczej, polegajacej na świadczeniu usług użyteczności publicznej. Sektor publiczny nie może jednak dominować; akceptowanie i uznanie jego doniosłości stanowiłoby bowiem zaprzeczenie istoty społecznej gospodarki rynkowej. Dominacja lub monopolizacja działalności gospodarczej przez sektor publiczny nie może wykraczać „ponad uzasadnione konstytucyjnie potrzeby”68 i należy dążyć do takiego jego miejsca w gospodarce, które potwierdzałoby uznanie tej obecności za wyjątek wobec prymatu własności prywatnej w gospodarce rynkowej.

Wyżej zarysowane stanowisko ustrojodawcy jest widoczne przez odstapienie od odnoszenia wobec podmiotów publicznych konstytucyjnych przesłanek i rygorów, które wiążą przy ograniczaniu wolności gospodarczej podmiotów prywatnych $^{69}$. Uprawnione jest zwłaszcza - w świetle orzecznictwa Trybunału Konstytucyjnego - nie tylko przyjmowanie rozwiązań, które reguluja przesłanki obecności podmiotów publicznych na rynku przez podejmowanie przedsiębiorczości. Wykonywanie przez władze publiczne funkcji publicznych w imieniu państwa jest okolicznością oraz przesłanką usprawiedliwiająca ingerencję normatywną w ich sytuację, kiedy ich intencją jest uczestnictwo w stosunkach obrotu gospodarczego. Władze publiczne nie są też uprawnione do korzystania z podmiotowego prawa wolności gospodarczej ${ }^{70}$. Rozwiązania kształtujące sytuację władz publicznych ujmują swoiście przede wszystkim szczegółowe zagadnienia podejmowania, wykonywania i kończenia działalności gospodarczej przez te władze ${ }^{71}$.

Władze publiczne uczestniczą w gospodarce rynkowej w prawem przewidzianych formach organizacyjnych. Utworzone przez nie w tym celu jednostki organizacyjne wyróżniają różnorodne treściowo powiązania z państwem $\mathrm{w}$ tym z jednostkami samorządu terytorialnego, co nadaje im status przedsiębiorców publicznych (podmiotów prawa publicznego). Do tej kategorii podmiotów zaliczamy także jednostki z udziałem sektora publicznego i sektora prywatnego, kiedy struktura majątkowa tych podmiotów została wypełniona składnikami mienia publicznego i mienia prywatnego ${ }^{72}$. Trybunał wyróżnia uprawnienia przedsiębiorców publicznych do udziału (uczestniczenia) w obrocie gospodarczym i wskazuje zarazem na odrębny i szczególny reżim prawny tej obecności ${ }^{73}$, charakteryzowany przejawami dominującego na nie wpływu ${ }^{74}$

${ }^{68}$ Wyrok TK z 7 maja 2001 r., K 19/00, OTK ZU 2001, nr 4, poz. 82.

${ }^{69}$ C. Kosikowski, Wolność gospodarcza w prawie polskim, Warszawa 1995, s. 76.

${ }^{70}$ Wyrok TK z 23 czerwca 1999 r., K 30/98, OTK ZU 1999, nr 5, poz. 101; wyrok TK z 14 grudnia 2004 r., K 25/03, OTK ZU 2004, 11/A, poz. 116.

${ }^{71}$ Wyrok TK z 21 października 2008 r., P 2/08, OTK ZU 2008, nr 8, poz. 139.

72 Wyrok TK z 7 maja 2001 r., K 19/00, OTK ZU 2001, nr 4, poz. 82.

${ }^{73}$ Wyrok TK z 7 maja 2001 r., K 19/00, OTK ZU 2001, nr 4, poz. 82, też: K. Strzyczkowski, Pojęcie przedsiębiorcy publicznego, „Przegląd Ustawodawstwa Gospodarczego” 2002, nr 2, s. 7 i n.

74 Postanowienie TK z 8 kwietnia 2008 r., SK 80/06, OTK ZU 2008, nr 3/A, poz. 51; też: S. Dudzik, Pomoc państwa dla przedsiębiorstw publicznych w prawie Wspólnoty Europejskiej, Kraków 2002, s. 97 i n. 
o różnych jego aspektach i intensywności czy też ich sytuacją majątkową ${ }^{75}$. Status ten jest zbudowany konstytucyjnie i ustawowo na szczególnych przesłankach, uzasadniających i wspierajacych działalność gospodarczą podmiotów publicznych oraz nią rządzących. W jego treści nie znajdujemy - w świetle komentowanego stanowiska Trybunału Konstytucyjnego - prawa podmiotowego do wolności gospodarczej w wyrazie, który przysługuje przedsiębiorcom prywatnym. „Państwowe jednostki organizacyjne w szerokim tego słowa znaczeniu nie sa adresatem konstytucyjnej gwarancji wolności działalności gospodarczej"76. Zasada wolności gospodarczej i wywodzona z niej zasada równości nie ma więc charakteru powszechnie obowiązującego w tym znaczeniu, że jest prawem podmiotowym adresowanym do przedsiębiorców prywatnych.

\section{VII}

Trybunał wskazał, że wyróżnienie w społecznej gospodarce rynkowej dwóch kategorii podmiotów obecnych w obrocie - prywatnych i publicznych wymaga przyjęcia jednoznacznych i czytelnych przesłanek dywersyfikujacych $^{77}$. Zarazem poszczególne podmioty lub ich grupy zaliczone do jednej z kategorii nie mogą być traktowane w sposób dyskryminujący lub faworyzujący ${ }^{78}$. Stwierdzenie to jednak ma różną miarę, jeżeli je weryfikujemy na tle sytuacji podmiotów gospodarujących, które przynależą do kategorii jednostek prywatnych albo do grupy podmiotów publicznych.

I tak - samodzielność jednostek prywatnych jest wywodzona „z praw i wolności przysługujących człowiekowi i obywatelowi”79. Ich udział w obrocie nie jest więc następstwem pozytywnej oceny władz publicznych co do zasadności zadecydowania o uczestniczeniu w przedsiębiorczości. W konsekwencji - samodzielność przedsiębiorców prywatnych przenosi się na różne działania (formy prawne działalności), które wypełniają wykonywanie przedsiębiorczości ${ }^{80}$. Rzecz zwłaszcza obejmuje sytuację podmiotów o mieszanej strukturze majątkowej - z udziałem mienia publicznego oraz mienia prywatnego. To „zmieszanie” w aspekcie majątkowym statusu podmiotowego jednostki organizacyjnej rodzi pytania o zasadność objęcia jej gwarancjami konstytucyjnymi przez uznanie prawa do wolności gospodarczej. Podobne wątpliwości można zgłaszać wobec sytuacji podmiotów gospodarczych, które zostały utworzone wyłącznie przez podmioty publiczne jednoosobowo lub z udziałem kilku podmiotów publicznych. Wprawdzie dominuje pogląd o postawieniu takich przedsiębiorców poza

75 Wyrok TK z 29 października 2010 r., P 34/08, OTK ZU 2010, nr 8/A, poz. 84. Por. M. Szydło, w: Traktat ustanawiajacy Wspólnotę Europejska, red. A. Wróbel, t. 3 (art. 61-188), red. K. Kowalik-Bańczyk, M. Szwarc-Kuczer, Warszawa 2009, s. 500 i n.

76 Wyrok TK z 7 maja 2001 r., K 19/00, OTK ZU 2001, nr 4, poz. 82.

77 Wyrok TK z 18 stycznia 2000 r., K 17/99, OTK ZU 2000, nr 1, poz. 4.

${ }^{78}$ Wyrok TK z 23 czerwca 1999 r., K 30/98, OTK ZU 1998, nr 5, poz. 101.

${ }^{79}$ Wyrok TK z 7 maja 2001 r., K 19/00, OTK ZU 2001, nr 4, poz. 82; inaczej Mirosław Granat w zdaniu odrębnym do postanowienia TK z 18 grudnia 2013 r., Ts 12/12.

${ }^{80}$ Wyrok TK z 7 maja 2001 r., K 19/00, OTK ZU 2001, nr 4, poz. 82. 
konstytucyjnym prawem wolności gospodarczej, wskazać jednak można na argumenty, które przeczą takiej tezie. Pośród nich najistotniejsze - jak można sądzić - znaczenie ma wyróżnienie przepisów wspólnych dla podmiotów prywatnych oraz publicznych, niezależnie od ich sytuacji majątkowej w znaczeniu opisanym wyżej, kiedy pozostają one w stosunku podległości wobec państwa (władz publicznych) w takim samym stopniu ${ }^{81}$.

W grupie podmiotów prywatnych (osób fizycznych) występuje jednak w pewnych okolicznościach ich sytuacji prawnej pewne zróżnicowanie statusu, które ma swoje źródło w ograniczeniach prawa do wolności. Przykładem są osoby fizyczne, znajdujące się w sytuacji funkcjonariuszy publicznych. Trybunał uznał, że zakazy prowadzące do ograniczenia przedsiębiorczości lub jej wykonywania ( $\mathrm{np}$. korzystanie z mienia publicznego) nie maja charakteru dyskryminującego (nierówne traktowanie). Obowiązują bowiem wobec wyróżnionej w prawie grupy osób, które charakteryzują się podobnymi cechami swojej sytuacji.

Ranga materii chronionych przez wprowadzenie ograniczeń (zaufanie opinii publicznej do władz publicznych, ochrona konstytucyjnych organów państwa, bezstronność i uczciwość) ${ }^{82}$ są tymi wartościami, które usprawiedliwiają wkraczanie przez ustawodawcę w sferę wolności obywatelskich ${ }^{83}$. Ingerencja ta nie została zarazem zaliczona do sfery dyskrecjonalnych prerogatyw władz publicznych. Ustawodawca został wprawdzie uprawniony do przyjmowania rozwiązań systematyzujacych sytuację podmiotów (osób) publicznych w gospodarce i wobec gospodarki, co może prowadzić do ograniczania woli tych podmiotów w wyborach, kiedy zamiarem prawodawcy jest ograniczanie wolności podmiotów sprawujących funkcje publiczne do przedsiębiorczości. Stanowisko ustawodawcy i innych władz uprawnionych do stanowienia prawa determinuja jednak wskazane wcześniej reguły, wywodzone z regulacji konstytucyjnych.

\section{VIII}

Pewność prawa jest wartością konstytucyjną i zarazem przesłanka gwarancyjna, która zapewnia przedsiębiorcom stabilizację ich sytuacji w stosunkach wzajemnych oraz - zwłaszcza - wobec władz publicznych. Zachowanie praw nabytych jest szczególną wartością sytuacji prawnej. Wyróżnione przez ustrojodawce prawo ustawodawcy do władczego oddziaływania na gospodarkę, aktualizowane w szczególnych warunkach rynkowych, nie oznacza tym samym przekazania władzom publicznym uprawnienia do zaskakiwania adresatów regulacjami, które stanowią o ingerencji w wolność przedsiębiorczości ${ }^{84}$. Treścią legalizmu działania odnoszonego do tych władz jest bowiem dbałość

\footnotetext{
81 Postanowienie TK z 18 grudnia 2013 r., Ts 13/12.

82 Wyrok TK z 13 lipca 2004 r., K 20/03, OTK ZU 2004, nr 7/A, poz. 63.

83 Wyrok TK z 23 czerwca 1999 r., K 30/98, OTK ZU 1999, nr 5, poz. 101.

${ }^{84}$ Wyrok TK z 10 października 2001 r., K 28/01, OTK ZU 2001, nr 7, poz. 212.
} 
o bezpieczeństwo prawne uczestników obrotu gospodarczego ${ }^{85}$. Z obowiązu tej pieczy nie wynika zarazem bezwzględny nakaz kierowania się przez władze publiczne regułą niezmienności prawa ${ }^{86}$. Zasada legalizmu nie prowadzi bowiem do wykluczenia możliwości zmiany sytuacji adresatów normatywnych aktów prawnych.

Gospodarkę rynkową charakteryzuje zmienność warunków wykonywania działalności gospodarczej, determinowana czynnikami obiektywnymi - niezależnymi od woli przedsiębiorców i władz publicznych. W konsekwencji ochrona praw nabytych podmiotów gospodarujących podlega ocenom z uwzględnieniem pewnej wrażliwości na te warunki czy skutki pozostające poza wolą państwa ${ }^{87}$. Sfera stosunków gospodarczych stwarza tym samym nieustanne wyzwania przed ustawodawca co do ujęcia praw nabytych wobec ograniczeń wolności gospodarczej i ich przesłanek ${ }^{88}$. „Szczególnie ważne względy lub okoliczności”89 są przesłankami usprawiedliwiajaccymi ingerencję w prawa nabyte.

Usprawiedliwiona ingerencja w prawa nabyte nie jest jednak kwestią autonomii woli władzy publicznej. Państwo jest zwłaszcza zobligowane do szczególnej przezorności w przypadkach zmiany prawa obowiązującego ${ }^{90}$. Przejawem takiej przezorności jest dyrektywa legislacyjna, którą Trybunał Konstytucyjny odnosi do zachowań władz publicznych wobec podmiotów przedsiębiorczości; zawiera się ona w postulacie ważenia interesu publicznego i prywatnego. Podobny pogląd jest wyprowadzany, gdy ustawodawca ogarnia prawami konstytucyjnymi sytuacje szczególne - np. odstępstwo od zakazu zmiany przepisów wobec osób pełniących funkcje publiczne ${ }^{91}$.

W sposób zbliżony rzecz przedstawia się z obowiązywaniem zakazu retroaktywności wobec regulacji, których przedmiotem są relacje przedsiębiorców z władzami publicznymi. Obowiązywanie zakazu jest uznawane przez Trybunał Konstytucyjny za specjalny przejaw poszanowania wolności przedsiębiorców. Stanowisko to jest wywodzone z zasady zaufania obywateli do państwa ${ }^{92}$, co obejmuje także sprawy przedsiębiorczości. Pogorszenie sytuacji prawnej adresatów wolności gospodarczej „w stosunku do stanu poprzedniego" ${ }^{93}$ jest szczególnym przejawem retroakcji. W istocie jest bowiem przejawem ingerencji w prawa adresatów. Sytuacja taka prowadzi do weryfikowania w sensie negatywnym ich konstytucyjnego prawa podmiotowego do wolności gospodarczej.

Trybunał Konstytucyjny znajduje usprawiedliwienie naruszenia konstytucyjnie ukształtowanego prawa wolności gospodarczej przez wprowadzanie do obiegu prawnego regulacji o skutkach retroaktywnych. Usprawiedliwieniem

\footnotetext{
85 Wyrok TK z 14 czerwca 2000 r., P 3/2000, OTK ZU 2000, nr 5, poz. 138.

86 Wyrok TK z 7 maja 2001 r., K 19/00, OTK ZU 2001, nr 4, poz. 82.

${ }^{87}$ Postanowienie SN z 18 stycznia 2005 r., SN WK 22/04, Lex, nr 145/63.

88 Wyrok TK z 8 kwietnia 1998 r., K 10/97, OTK ZU 1998, nr 3, poz. 29.

89 Wyrok TK z 20 sierpnia 1992 r., K 4/92, OTK ZU 1994, cz. II, s. 19 i n.

${ }_{90}$ Postanowienie SN z 18 stycznia 2005 r., SN WK 22/04, Lex, nr 145/63.

91 Wyrok TK z 23 czerwca 1999 r., K 30/98, OTK ZU 1999, nr 5, poz. 101.

92 Wyrok TK z 10 października 2001 r., K 28/01, OTK ZU 2001, nr 7, poz. 212.

${ }^{93}$ Orzeczenie TK z 19 stycznia 1992 r., K 15/91, OTK ZU w latach 1986-1995, t. 3, poz. 8.
} 
jest ochrona innych wartości konstytucyjnych, jeżeli znajduje ona uzasadnienie w szczególnych okolicznościach. W takich sytuacjach należy rozważać dwie przesłanki, pozostające wobec siebie w zależnościach konfrontacyjnych: doniosłość znaczenia wartości chronionych (,sytuacje nadzwyczaj wyjątkowe”) ${ }^{94}$, które podlegają ochronie z naruszeniem zakazu nieretroaktywności, oraz troska o wolność gospodarcza, jeżeli wolność ta jest zagrożona przez jej ograniczenie lub zniesienie w związku z zamierzonymi i przyjmowanymi w takich szczególnych sytuacjach regulacjami retroaktywnymi. Ustawodawca winien zwłaszcza dochować szczególnej staranności przy ujmowaniu przepisów oceniających zdarzenia „stare” w świetle nowej regulacji ${ }^{95}$. Przedsiębiorca nie może zarazem zostać osamotniony wobec wyzwań, które niesie dla jego interesu taka sytuacja.

Wolność przedsiębiorczości gwarantują także remedia prawne, które wkraczaja na pola konstytucyjnie i ustawowo zastrzeżone do wykonywania wolnej woli. Podmiot wolności gospodarczej korzysta ze swobody podejmowania i wykonywania przedsiębiorczości przede wszystkim w stosunkach obrotu gospodarczego z innymi podmiotami wolności gospodarczej, kiedy organizuje swoja przedsiębiorczość przez uwzględnienie właściwych regulacji prawa przedmiotowego. Wyznaczają one zarazem i legitymizują jego zachowania czy też kształtują relacje wobec władz publicznych.

Przedsiębiorca jako strona w stosunkach wertykalnych jest konfrontowany z władzami publicznymi szczególnie w sytuacjach, kiedy podejmują one działalność w celu załatwiania spraw z zakresu administracji publicznej. Działalność tę wypełniają przede wszystkim akty administracyjne o różnym przedmiocie (regulujące różne sprawy). W tych sprawach łącznikiem między działalnością władz publicznych oraz roszczeniami o świadczenia na rzecz podmiotów gospodarki rynkowej lub zaniechania ingerencji jest interes prawny przedsiębiorcy lub innych podmiotów wykonujacych działalność gospodarczą. Interes ten wywodzą one $\mathrm{z}$ właściwego $\mathrm{w}$ sprawie przepisu prawa ${ }^{96}$. Wolność bez środków prawnych, które aktualizują prawo do formułowania żądań o zaniechania lub do wysuwania określonych roszczeń w związku z naruszeniami wolności ${ }^{97}$, staje się tylko ornamentem słownym stanowiska prawodawcy, które w istocie przyjmuje wyraz bezwartościowej deklaracji. Podmioty wolności działalności gospodarczej znajdują się wówczas w sytuacji opuszczenia w swojej wolności wobec jej zagrożeń czy naruszeń.

Konstytucja powierza państwu ochronę wolności - w tym wolności gospodarczej (art. 5: „Państwo strzeże”). Ochrona ta zakorzeniona jest w treści interesu publicznego ${ }^{98}$ przede wszystkim w tym znaczeniu, że w interesie publicz-

94 Orzeczenie TK z 19 października 1993 r., K 14/92, ZU 1993, poz. 35; OTK 1986-1995, t. 4, 1993, cz. 2, poz. 35.

${ }_{95}$ Wyrok TK z 7 maja 2001 r., K 19/00, OTK ZU 2001, nr 4, poz. 82.

96 Wyrok NSA z 29 grudnia 2009 r., II OSK 1843/09, Centralna Baza Orzeczeń Sądów Administracyjnych.

${ }^{97}$ K. Kiczka, Administracyjnoprawne środki kształtowania sytuacji prawnej przedsiębiorców, op. cit., s. 368 .

98 Wyrok NSA z 26 maja 1981 r., SA 811/81, ONSA 1981/1, poz. 46. 
nym jest zapobieganie naruszeniom prawa czy też ich znoszenie (usuwanie) ${ }^{99}$. W interesie publicznym leży także ochrona prawna wolności gospodarczej przez ustanowienie odpowiednich gwarancji publicznoprawnych - zwłaszcza weryfikujących zakaz „bezprawnej ingerencji” ${ }^{100}$. Podmiot wolności działalności gospodarczej jest bowiem uprawniony i wywodzić może z treści wolności gospodarczej, zrekonstruowanej i przyjmowanej przez Trybunał Konstytucyjny na tle rozwiązań Konstytucji, umocowanie do jej ochrony (uprawnienie do ochrony prawa podmiotowego) ${ }^{101}$. Prawo podmiotowe do wolności gospodarczej oznacza tym samym nie tylko stanowienie o celowości podejmowania czy wykonywania działalności gospodarczej. Mieści się w nim także prerogatywa do formułowania żądań określonego zachowania (zaniechania naruszeń ${ }^{102}$, przywrócenia stanu poprzedniego $\left.{ }^{103}\right)$, adresowanych do właściwych władz publicznych. W tym znaczeniu prawo do wolności gospodarczej jako prawo podmiotowe ma charakter roszczeniowy ${ }^{104}$ przez żądanie określonych świadczeń pozytywnych ${ }^{105}$; mają one charakter gwarancyjny i pozwalają na wykonywanie działalności gospodarczej w warunkach wolności gospodarczej - zwłaszcza w warunkach konkurencji ${ }^{106}$.

\section{IX}

Członkostwo „w strukturach Unii Europejskiej”"107 kieruje uwagę na regulacje prawa europejskiego w ocenach istoty, przejawów i zasadności ingerencji w wolność przedsiębiorczości. Uprawnione jest więc spojrzenie na wolność gospodarczą i jej granice, ujęte w wymiarze krajowym, przez uwzględnienie „terminologii, pojęć i zasad”, które sa znane prawu europejskiemu. Wolność gospodarcza nabiera tym samym wymiaru europejskiego. Trybunał wskazywał na regulacje prawa Unii Europejskiej i ich znaczenie również przy charakteryzowaniu konstytucyjnych granic wolności gospodarczej (art. 22) ${ }^{108}$.

Relacje między prawem polskim a prawem europejskim znalazły swoje ważne miejsce w opisach doktryny różnych dziedzin prawa. Interpretacje wolności przedsiębiorczości uwzględniać powinny „ducha prawa wspólnotowego”. Takie podejście w rozważaniach o wolności gospodarczej jest ważne zwłasz-

${ }_{99}$ M. Maciołek, O publicznym prawie podmiotowym, „Samorząd Terytorialny” 1992, nr 1-2, s. 4 .

${ }^{100}$ K. Wojtyczek, Granice ingerencji ustawodawczej $w$ sfere praw człowieka $w$ Konstytucji RP, s. 50 .

101 Wyrok SN z 4 czerwca 1982 r., I CR 151/82, OSN CA 1983, nr 2-3, poz. 41.

${ }_{102}$ Materiaty do nauki prawa administracyjnego (M. Kulesza - red.), Warszawa 1989, s. 125.

${ }^{103}$ K. Kiczka, Administracyjnoprawne środki ksztattowania sytuacji prawnej przedsiębiorców, op. cit., s. 369; Materiaty do nauki prawa administracyjnego, op. cit., s. 131.

${ }^{104}$ K. Klecha, Wolność działalności gospodarczej w Konstytucji RP, Warszawa 2009, s. 54.

${ }^{105}$ K. Kiczka, Administracyjnoprawne środki ksztattowania sytuacji prawnej przedsiębiorców, op. cit., s. 367; Materiaty do nauki prawa administracyjnego, op. cit., s. 131.

106 Wyrok SN z 12 września 2008 r., I PK 27/08, OSNP 2010, nr 3-4, poz. 34

107 Wyrok TK z 21 kwietnia 2004 r., K 33/03, OTK ZU 2004, nr 4/A, poz. 31.

108 Wyrok TK z 21 kwietnia 2004 r., K 33/03, OTK ZU 2004, nr 4/A, poz. 31. 
cza w sytuacji określanej jako deficyt regulacji prawnych, jeżeli ustawodawca poza polem swojej uwagi pozostawia unormowanie pewnych zagadnień, co stanowi naruszenie wymogu harmonizacji prawa wewnętrznego z prawem europejskim i innymi systemami krajowymi. Prowspólnotowe podejście również winno kierować wykładnią prawa wewnętrznego, kiedy jego regulacje nie sa jednoznaczne w treści czy też pozwalają na różne wybory w ich interpretacji.

Istnieje pewien szczególny wzorzec brany pod uwagę w ocenach na temat celowości czy zasadności uwzględniania prawa europejskiego w analizach sporządzanych, aby ustalić znaczenie i treść instytucji prawnych, które wyznaczają miejsce wolności przedsiębiorczości w konstytucyjnym porządku prawnym. Wzorcem tym jest stanowisko Trybunału Konstytucyjnego, że to Konstytucja RP „pozostaje [...] najwyższym prawem Rzeczypospolitej”109. W świetle tego stanowiska wykładnia proeuropejska (przyjazna prawu europejskiemu) nie może więc prowadzić do marginalizacji ustawy zasadniczej. Stwierdzenie to nadal broni się, jeżeli odniesiemy je do fundamentalnych zasad porządku konstytucyjnego. Powyżej zarysowane stanowisko odnoszę do regulacji, które wyznaczają „wrażliwe” społecznie czy politycznie skutki członkostwa w UE dla suwerenności państwa czy konsekwencje członkostwa dla interpretacji szczególnych zagadnień wywodzonych z praw i wolności obywatelskich. Przyjęte w treści Konstytucji unormowania, podstawowe dla praw i wolności obywatela oraz ustroju RP, w istocie wyznaczaja granice swobody ustawodawcy wewnętrznego w wyborach regulacyjnych, determinowanych treścią rozwiązań prawa europejskiego.

W świetle wskazanego wyżej stanowiska rola Trybunału Konstytucyjnego ograniczać się winna przede wszystkim do weryfikowania zgodności aktów normatywnych ze standardami konstytucyjnymi (,tradycyjny defensywny konstytucjonalizm") ${ }^{110}$, co jest sprowadzane do obrony owych fundamentalnych czy podstawowych wartości konstytucyjnych. Do kategorii takich wartości należy niewątpliwie wolność działalności gospodarczej. Wolność przedsiębiorczości jest fundamentem, na którym zbudowano także europejski ład współpracy gospodarczej w unijnym ugrupowaniu integracyjnym. Zasady owego porządku oraz podstawowe treści wyznaczają regulacje prawa unijnego.

Pogląd o uwzględnianiu kryterium tożsamości konstytucyjnej przy wyznaczeniu granicy wkraczania przez prawo europejskie w polski porządek prawny $^{111}$ jest nośny w dyskusjach publicznych, a ta jego atrakcyjność zależy zwłaszcza od sposobu jego ujęcia i prezentacji. Wydaje się uzasadnione rozważanie w sposób pogłębiony problematyki intensywności i skutków owego wkraczania przez prawo europejskie w wewnętrzny porządek prawny także na gruncie regulacji zaliczanych do publicznego prawa gospodarczego. Pozostaje tym samym - jak sądzę - pewnym wyzwaniem dla nauki publicznego prawa gospodarczego ocena konsekwencji związania ustawodawcy polskiego

\footnotetext{
${ }_{109}$ Wyrok TK z 11 maja 2005 r., K 18/04, OTK ZU 2005, nr 5/A, poz. 49.

110 T. Koncewicz, Trybunat Konstytucyjny w Europie, „Rzeczpospolita” z 10 marca 2014 r., s. C8.

${ }^{111}$ K. Kowalik-Bańczyk, w: S. Dudzik, N. Półtorak (red.), Prawo Unii Europejskiej a prawo konstytucyjne państw członkowskich, Warszawa 2013, s. 44.
} 
prawem europejskim, jeżeli uwzględnimy stanowisko Trybunału Konstytucyjnego o nieprzekraczalnych granicach związania, wyznaczonych przez podstawowe wartości promowane przez polską Konstytucję. Kwestia ta dzisiaj znajduje wprawdzie swoje miejsce w dyskusjach, widać jednak w nich raczej nachylenie ku weryfikacji stanowiska ustawodawcy polskiego - z uwzględnieniem zasady zgodności rozwiązań szczegółowych właściwych dla przedsiębiorczości - ze stanowiskiem prawodawcy unijnego oraz Trybunału Sprawiedliwości UE (przystosowanie prawa wewnętrznego do europejskich regulacji szczegółowych). Tymczasem skutkiem pierwszeństwa prawa europejskiego, jego bezpośredniego stosowania czy bezpośredniej skuteczności w prawie krajowym może się okazać przełamywanie czy co najmniej zmiana tożsamości konstytucyjnej tych wartości, które Trybunał Konstytucyjny zaliczył do podstaw polskiego porządku konstytucyjnego. W tej właśnie perspektywie widzę wykraczanie przez Trybunał poza granice wskazanej wyżej postawy „defensywnej" w interpretacjach zgodności aktów normatywnych z Konstytucja. Ten swego rodzaju „aktywizm interpretacyjny” uwzględniajacy w analizach także perspektywę europejskich regulacji prawnych może prowadzić do weryfikacji treści czy wzorców konstytucyjnych, które Trybunał uwzględnia w badaniach zgodności z Konstytucją regulacji normatywnych. W istocie chodzi nie tylko o ustalenie granic możliwości ochrony wartości ujętych w prawie europejskim. Pewną powinnością nauki publicznego prawa gospodarczego jest rozważenie, czy w świetle przytoczonego wyżej stanowiska Trybunału Konstytucyjnego regulacje publicznego prawa gospodarczego, uwzględniajace stanowisko prawodawcy europejskiego, nadal mieszczą się w owych „nieprzekraczalnych granicach", czy tė̇ raczej rysuje się w nich tendencja nadawania wartościom konstytucyjnym, w tym zwłaszcza wolności gospodarczej, tożsamości, która jest wyrazem co najmniej zmiany podejścia ustawodawcy polskiego w rozumieniu tej wolności.

prof. dr hab. Leon Kieres

Uniwersytet Wroctawski

oraz Sędzia Trybunatu Konstytucyjnego

lkier@prawo.uni.wroc.pl

\title{
CONSTITUTIONAL PUBLIC ECONOMIC LAW
}

\author{
Sum mary
}

Economic freedom is a fundamental constitutional value. It is subject to interpretation by the judgments of the Constitutional Court as a constitutional principle and constitutional right. The purpose of this interpretation is to establish the location of economic freedom in constitutional terms of the social market economy and to determine its characteristic features (identity).Economic freedom also defines the position of the legislator who recognises entrepreneurship issues in statutory regulations, and takes into account the position of the Constitutional Court on the principles of law-making. The European Union law also plays an important role in shaping the characteristics of economic freedom. The study of public economic law should combine the constitutional recognition of economic freedom with its understanding in ordinary legislation and case law by taking into account the European perspective. 
Copyright of Journal of Law, Economics and Sociology is the property of Faculty of Law and Administration of Adam Mickiewicz University in Poznan and its content may not be copied or emailed to multiple sites or posted to a listserv without the copyright holder's express written permission. However, users may print, download, or email articles for individual use.

Właścicielem praw autorskich do „Ruchu Prawniczego, Ekonomicznego i Socjologicznego” jest Wydział Prawa i Administracji Uniwersytetu im. Adama Mickiewicza w Poznaniu. Zawartość czasopisma nie może być kopiowana, przesyłana do innych stron internetowych bądź zamieszczana na blogach bez pisemnej zgody wydawcy. Niemniej artykuły można drukować, kopiować lub przesyłać w formie elektronicznej na własny użytek. 